\title{
Assessment of some heavy metals and histological alterations in gills and muscles of Oreochromis niloticus from Lake Nasser, Egypt
}

\author{
Hanan S. Gaber, Mohamed Y. Mohamed, EL-Kashif M.M. and AL-AFIFY, A.D.G. \\ National Institute of Oceanography and Fisheries, Cairo, Egypt
}

\begin{abstract}
The concentration of some heavy metals ( $\mathrm{Fe}, \mathrm{Zn}, \mathrm{Cu}, \mathrm{Pb}$, and $\mathrm{Cd}$ ) in gills and muscle of Oreochromis niloticus obtained from four khores (El-Madiq, Amada, Tushka, and Dahmit) of Lake Nasser, Egypt during winter (January) and spring (May) 2016 was investigated using atomic absorption spectrophotometry and the histological alterations in these organs were also studied.

The present results indicated that the accumulations of $\mathrm{Fe}, \mathrm{Zn}, \mathrm{Pb}$, and $\mathrm{Cd}$ exceeded the recommended limit in fish gills. However, the levels of $\mathrm{Fe}$ and $\mathrm{Zn}$ exceeded the recommended limit in muscles. Cu level was the lowest one in gills and muscles.

Bioaccumulation factor (BAF) listed high score for $\mathrm{Fe}, \mathrm{Pb}$, and $\mathrm{Cd}$ in gills during the spring season at Dahmit khore. While Fe and Zn listed high score in the muscles of fish at Dahmit khore.

Histopathological alterations recorded in gills of O.niloticus in this study including hyperplasia of the epithelium which led to a fusion of lamellae, epithelial lifting, aleukocytes infiltration and severe necrotic change. On the other hand, muscles of the investigated fish showed severe edema and splitting muscle fibers as a result of the accumulated metals.
\end{abstract}

Key word: Lake Nasser, Oreochromis niloticus, heavy metals, gills, muscles, histology.

\section{INTRODUCTION}

It is well known that human activities induce stress on ecological systems by importing pollutants, modifying habitats, introducing exotic species or removing the native ones and by changing the climate. These activities not only affect the survival or the performance of individual organisms, but also the structure and function of natural ecosystems and the diversity of life at several levels of the organization, including the numbers of species, the genetic composition, and the variety of ecosystems and landscapes (López-Barea, 1995). Contamination of aquatic ecosystems with heavy metals has long been recognized as a serious pollution problem. When fish are exposed to elevated levels of metals in a polluted aquatic ecosystem, they tend to take these metals up from their direct environment (Seymore, 1994). The aquatic environment with its water quality is considered the main factor controlling the state of health and disease in both human and animals. It has been recognized for many years that the concentrations of metals found in coastal areas, whether they are in the dissolved or particulate phases are derived from a variety of anthropogenic and natural sources (Burridge et al., 1999).

The increasing use of the waste chemical and agricultural drainage systems represents the most dangerous chemical pollution. Industrial and agricultural activities also significantly contribute to the accumulation of pollutants in the aquatics including fresh water (Jordao et al., 2002).Fish species are often the top consumers in aquatic ecosystems and thus metal concentrations in fish can act as an environmental indicator of the state of the environment (Rashed, 2001). Poleksić et al. (2010) explain that the histological alterations in selected target organs are sensitive biomarkers for xenobiotic effects; they occur earlier and 


\section{Hanan S. Gaber et al.}

provide a better evaluation of the effects of aquatic pollution than any single biochemical parameter.

This study determined the levels of some selected heavy metals $(\mathrm{Fe}, \mathrm{Zn}, \mathrm{Cu}, \mathrm{Pb}$ and $\mathrm{Cd}$ ), in gills and muscles tissues of Oreochromis niloticus from the lake Nasser and the effect of these metals on the histological structures of its gills and muscles. Also, to indicate if such metal contents and the alteration in histology of gills, and muscles can be used as bioindicators of fish health and fresh water pollution as well as the suitability of fish from the studied area of the lake Nasser for human consumption.

\section{Study area:}

\section{MATERIALS AND METHODS}

Lake Nasser represents a central water bank of Egypt and is one of the longest manmade lakes in the world which was formed after the construction of Aswan High Dam. Lake Nasser has a long and narrow shape with dendrites side areas called khores, the shallow water of which provides a good habitat for aquatic plants and planktons which are the suitable source of food for natural fish culture. Oreochromis.niloticus forms a common population of fish species in the lake with an average of $93 \%$ of total production. This study involved four sites along the south and North sites (Amada, El-Madiq, Tushka, and Dahmit). These khores are shown in Figure (1).

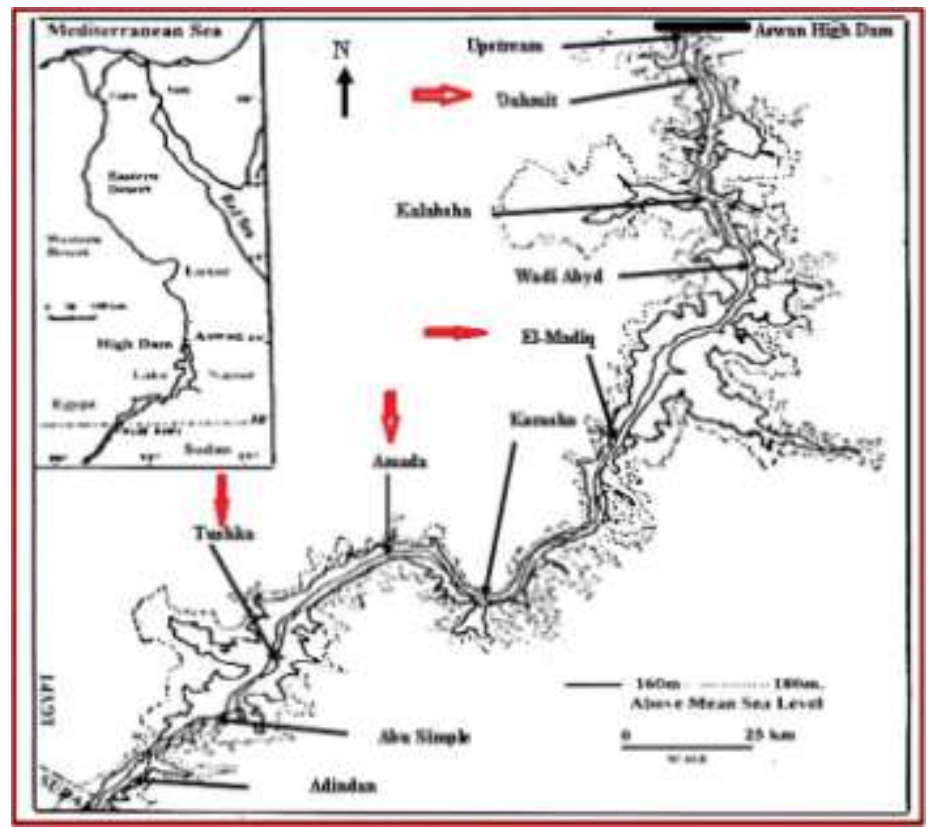

Fig. 1: Map showing the studied khores in Lake Nasser (Tushka, Amada, EL-Madiq and Dahmit).

\section{Water samples collection and analysis}

The sampling, preservation and experimental procedure of water samples were carried out according to the standard methods for the examination of water and wastewater (APHA, 1998).

\section{1-Physicochemical analysis of water:}

Surface water temperature $\left({ }^{\circ} \mathrm{C}\right)$ was measured by a dry mercury thermometer and hydrogen ion concentration $(\mathrm{pH})$ by $\mathrm{pH}$ meter from different four khores. Water samples were collected from the surface (10 samples/ season); using plastic bottles (1.5-liter capacity). 


\section{Assessment of some heavy metals and histological alterations in gills and muscles of Oreochromis niloticus from Lake Nasser, Egypt}

One-liter plastic bottles were also filled with water samples for undertaking the rest of chemical analysis. The samples were preserved in an icebox and returned immediately to the laboratory. Dissolved oxygen (DO) was measured using the modified Winkler method, biochemical (BOD) and chemical oxygen demands (COD) were determined with the 5-days incubation method. The concentration of ammonia $\left(\mathrm{NH}_{3}\right)$ was determined using the colorimetric techniques.

\section{2-Heavy metals analysis in water}

For heavy metals analysis, water samples were collected in one-liter plastic bottles and preserved with $5 \mathrm{ml}$ concentrated nitric acid on the spot and stored in the refrigerator (APHA, 1998). Heavy metals (Iron, Zinc, Copper, lead, and Cadmium) in water samples were determined, after digestion using Graphite Furnace AA (GFAA) spectroscopy. A mixture of nitric acid and sample was refluxed in a covered Griffin beaker. After the digestate has been brought to a low volume, it was cooled and brought up in dilute nitric acid (3\% v/v). The sample was filtered, allowed setting and prepared it for analyzer according to the standard methods for the examination of water and wastewater (APHA, 1998).

\section{3-Fish samples collection and analysis:}

Samples of the Nile tilapia $O$. niloticus were collected in two seasons (winter and spring) (15 fish/ season) from each khore. Fish were transposed alive back after catching to the laboratory for subsequent analysis. In the laboratory, for each fish, the total length and total weight were recorded. The fish total length and total weight were from $15-27.5 \mathrm{~cm}$ and from $66-175 \mathrm{~g}$, respectively.

Heavy metals (Iron, Zinc, Copper, Lead, and Cadmium) in fish samples were determined, after dissection of fish samples, the gills and muscle were collected and prepare for heavy metals analysis. Tissue samples were digested after drying (Ghazaly, 1988). The levels of each metal were measured by using atomic absorption spectrophotometer.

The ratio between the accumulated concentration of a given pollutant in any organ and its dissolved concentration in water is the Bioaccumulation Factor (BAF). It gives an indication of the accumulation efficiency for any particular pollutant in any fish organ. Bioaccumulation Factor (BAF) was calculated according to Authman and Abbas (2007) using the following equation:

$\mathrm{BAF}=$ Pollutant conc. in fish organ $(\mathrm{mg} / \mathrm{kg}) /$ Pollutant conc.in water $(\mathrm{mg} / \mathrm{L})$

\section{Histopathological Examination:-}

Samples of Oreochromis niloticus were collected from four khores in Lake Nasser. Fish were dissected and tissue specimens of muscles and gills were immediately isolated and fixed in $10 \%$ neutral formaldehyde for $24 \mathrm{hrs}$. After fixation, the tissues were washed in $70 \%$ ethyl alcohol to get rid of excess fixative and then dehydrated through ascending grades of ethyl alcohol. The specimens were cleared in xylene for 15-20 min and infiltrated with and embedded in paraffin wax. The paraffin wax block was sectioned at the thickness (5-6 $\mu$ ). Sections were stained with Harris' hematoxylin and eosin (Hx \& E).

\section{Statistical analysis:}

The data were computed, the basic statistics, means and standard deviations and errors of the measured parameters were estimated. Data were statistically analyzed using one-way analysis of variance (ANOVA). 


\section{Hanan S. Gaber et al.}

\section{RESULTS}

\section{1--Physicochemical Parameters:}

Table (1) shows the range values of physicochemical parameters of the sampling khores. It was obvious that the range values of the North part of Lake Nasser (Dahmit Khore) parameters of water differ from those collected from other khores of the southern part (Amada, EL-Madiq, and Tushka) where they were high in the winter than in the spring with the exception of temperature and BOD in both parts. Also, the present results cleared depletion in DO values in spring with increasing in ammonia at all khores.

Table (1). Range of physicochemical water parameters of the studied Khores of Lake Nasser.

\begin{tabular}{|c|c|c|c|c|}
\hline & Tushka -Am & -Madiq & Dahmit & \\
\hline parameters & winter & Spring & winter & Spring \\
\hline Temp ${ }^{\circ} \mathrm{C}$ & $18-21$ & $17.1-19.5$ & $17.1-19.5$ & $25-32$ \\
\hline $\mathrm{pH}$ & $8.3-9.0$ & $8.6-9.4$ & $8.6-9.4$ & $8.2-8.6$ \\
\hline $\mathrm{DO} \mathrm{mg} / \mathrm{l}$ & $6.4-8.2$ & $6.1-9.1$ & $6.1-9.1$ & $2.0-6.0$ \\
\hline BOD mg/l & $0.8-3.1$ & $0.6-2.1$ & $0.6-2.1$ & $0.0-4.1$ \\
\hline COD mg/l & $4.1-10.1$ & $6.4-14.3$ & $6.4-14.3$ & $2.0-12$ \\
\hline $\mathrm{NH}_{3} \mathrm{mg} / \mathrm{l}$ & $0.005-0.09$ & $0.002-0.03$ & $0.002-0.03$ & $0.097-0.20$ \\
\hline
\end{tabular}

Table (2): Heavy metal concentration (mg/l) in water from the studied khores of Lake Nasser during the winter and spring seasons, 2016 (means +SD).

\begin{tabular}{|c|c|c|c|c|c|c|c|}
\hline \multirow[b]{2}{*}{ Metal } & \multirow[b]{2}{*}{ Season } & \multicolumn{6}{|c|}{ khores } \\
\hline & & Tushka & Amada & El-Madiq & Dahmit & $\begin{array}{c}\text { Permissible } \\
\text { limit } \\
\text { Egyptian } \\
\text { law }\end{array}$ & $\begin{array}{c}\text { Permissible } \\
\text { limit } \\
\text { USEPA }\end{array}$ \\
\hline \multirow{2}{*}{$\mathbf{F e}$} & winter & $0.168 \pm 0.029$ & $0.170 \pm 0.02$ & $0.146 \pm 0.25$ & $0.150 \pm 0.027$ & \multirow[t]{2}{*}{0.1} & \multirow[t]{2}{*}{0.1} \\
\hline & spring & $0.056 \pm 0.0074$ & $0.22 \pm 0.016$ & $0.185 \pm 0.027$ & $0.0028 \pm 0.00016$ & & \\
\hline \multirow[b]{2}{*}{ Zn } & winter & $0.072 \pm 0.005$ & $0.068 \pm 0.013$ & $0.045 \pm 0.014$ & $0.074 \pm 0.006$ & \multirow[t]{2}{*}{0.1000} & \multirow[t]{2}{*}{0.120} \\
\hline & spring & $0.056 \pm 0.0074$ & $0.07 \pm 0.0036$ & $0.053 \pm 0.032$ & $0.0004 \pm 0.0002$ & & \\
\hline \multirow[b]{2}{*}{$\mathrm{Cu}$} & winter & $0.002 \pm 0.0001$ & $0.003 \pm 0.0002$ & $0.002 \pm 0.0003$ & $0.0025 \pm 0.0007$ & \multirow[t]{2}{*}{0.1} & \multirow[t]{2}{*}{0.009} \\
\hline & spring & $0.004 \pm 0.0002$ & $0.002 \pm 0.0001$ & $0.0047 \pm 0.0002$ & $0.0028 \pm 0.00017$ & & \\
\hline \multirow[b]{2}{*}{$\mathbf{P b}$} & winter & $0.0044 \pm 0.0002$ & $0.006 \pm 0.001$ & $0.007 \pm 0.0002$ & $0.0058 \pm 0.0002$ & \multirow[t]{2}{*}{0.005} & \multirow[t]{2}{*}{0.0025} \\
\hline & spring & $0.005 \pm 0.0003$ & $0.008 \pm 0.0002$ & $0.005 \pm 0.0003$ & $0.0005 \pm 0.0003$ & & \\
\hline \multirow[b]{2}{*}{ Cd } & winter & $0.0032 \pm 0.0002$ & $0.002 \pm 0.0003$ & $0.002 \pm 0.0001$ & $0.0018 \pm 0.0002$ & \multirow[t]{2}{*}{0.001} & \multirow[t]{2}{*}{0.00025} \\
\hline & spring & $0.0028 \pm 0.00015$ & $0.003 \pm 0.00016$ & $0.003 \pm 0.0002$ & $0.0007 \pm 0.0005$ & & \\
\hline
\end{tabular}

\section{2-Heavy Metals in Water}

Data reported in Table (2) indicated that the values of the detected heavy metals in the water samples from the investigated khores during winter and spring were less than permissible limit. The mean values of the elements at different khores showed that Fe was the most abundant element recorded [0.146 mg/l (EL-Madiq)-0.170 mg/l (Amada)] in winter and $[0.22 \mathrm{mg} / \mathrm{l}$ (Amada)] in spring, Whereas, $\mathrm{Cd}$ and $\mathrm{Cu}$ got the least concentration recorded [0.001 $-0.0032 \mathrm{mg} / \mathrm{l}]$ in winter and $[0.0007-0.003 \mathrm{mg} / \mathrm{l}]$ in spring for $\mathrm{Cd},(0.002-0.003 \mathrm{mg} / \mathrm{l})$ in winter, $(0.002-0.0047 \mathrm{mg} / \mathrm{l})$ in spring for $\mathrm{Cu}$. However, $\mathrm{Pb}$ and $\mathrm{Zn}$ showed the lowest concentrations in Dahmit and in Amada (0.0005, $0.0004 \mathrm{mg} / \mathrm{l})$, while Zn showed the highest concentration $(0.07 \mathrm{mg} / \mathrm{l})$ in spring. 


\section{Assessment of some heavy metals and histological alterations in gills and muscles of Oreochromis niloticus from Lake Nasser, Egypt}

\section{Metals Concentration in fish: \\ Muscles:}

Table (3) showed the concentrations of the analyzed metals in the muscle of fish from Nasser Lakes during winter season. Metal concentrations in Oreochromis niloticus from Amada Khore of the Lake recorded, Cd $(0.3 \mathrm{mg} / \mathrm{kg}$ dry weight $)<\mathrm{Pb}(0.04 \mathrm{mg} / \mathrm{kg}$ dry weight $)$ $<\mathrm{Cu}(0.05 \mathrm{mg} / \mathrm{kg}$ dry weight $)<\mathrm{Zn}(0.22 \mathrm{mg} / \mathrm{kg}$ dry weight $)<\mathrm{Fe}(4.49 \mathrm{mg} / \mathrm{kg}$ dry weight $)$, $\mathrm{Cd}(0.02 \mathrm{mg} / \mathrm{kg}$ dry weight $)<\mathrm{Pb}(0.02 \mathrm{mg} / \mathrm{kg}$ dry weight $)<\mathrm{Cu}(0.06 \mathrm{mg} / \mathrm{kg}$ dry weight $)<$ $\mathrm{Zn}(0.65 \mathrm{mg} / \mathrm{kg}$ dry weight $)<\mathrm{Fe}(4.4 \mathrm{mg} / \mathrm{kg}$ dry weight $)$ in EL-Madiq, Cd $(0.05 \mathrm{mg} / \mathrm{kg}$ dry weight $)<\mathrm{Pb}(0.03 \mathrm{mg} / \mathrm{kg}$ dry weight $)<\mathrm{Cu}(0.07 \mathrm{mg} / \mathrm{kg}$ dry weight $)<\mathrm{Zn}(1.41 \mathrm{mg} / \mathrm{kg}$ dry weight $)<\mathrm{Fe}(5.07 \mathrm{mg} / \mathrm{kg}$ dry weight $)$ in Dahmit khore, Cd $(0.03 \mathrm{mg} / \mathrm{kg}$ dry weight $)<\mathrm{Pb}$ $(0.14 \mathrm{mg} / \mathrm{kg}$ dry weight $)<\mathrm{Cu}(0.03 \mathrm{mg} / \mathrm{kg}$ dry weight $)<\mathrm{Zn}(0.67 \mathrm{mg} / \mathrm{kg}$ dry weight $)<\mathrm{Fe}$ (4.48 mg/kg dry weight) in Tushka khore (Table 3).

The trend of accumulation each metal was as follows: $\mathrm{Cu}$, Dahmit > EL-Madiq > Amada > Tushka. Cd, Tushka $>$ Dahmit > Amada > EL-Madiq. Pb, Tushka> Amada> Dahmit> EL-Madiq. Zn, Dahmit> Tushka> EL-Madiq> Amada. Fe, Tushka> Dahmit> Amada> EL-Madiq (Table 3).

During spring season, the accumulation of metals in fish muscle showed $\mathrm{Cu}(0.03$ $\mathrm{mg} / \mathrm{kg}$ dry weight $)<\mathrm{Pb}(0.06 \mathrm{mg} / \mathrm{kg}$ dry weight $)<\mathrm{Cd}(0.08 \mathrm{mg} / \mathrm{kg}$ dry weight $)<\mathrm{Zn}(0.24$ $\mathrm{mg} / \mathrm{kg}$ dry weight $)<\mathrm{Fe}(5.7 \mathrm{mg} / \mathrm{kg}$ dry weight $)$ in Amada khore, $\mathrm{Cu}(0.02 \mathrm{mg} / \mathrm{kg}$ dry weight $)$ $<\mathrm{Pb}(0.05 \mathrm{mg} / \mathrm{kg}$ dry weight $)<\mathrm{Cd}(0.05 \mathrm{mg} / \mathrm{kg}$ dry weight $)<\mathrm{Zn}(0.87 \mathrm{mg} / \mathrm{kg}$ dry weight $)<$ Fe $(6.67 \mathrm{mg} / \mathrm{kg}$ dry weight $)$ in EL-Madiq khore, $\mathrm{Cu}(0.06 \mathrm{mg} / \mathrm{kg}$ dry weight $)<\mathrm{Pb}(0.07$ $\mathrm{mg} / \mathrm{kg}$ dry weight $)<\mathrm{Cd}(0.08 \mathrm{mg} / \mathrm{kg}$ dry weight $)<\mathrm{Zn}(1.66 \mathrm{mg} / \mathrm{kg}$ dry weight $)<\mathrm{Fe}(6.88$ $\mathrm{mg} / \mathrm{kg}$ dry weight $)$ in Dahmit khore, $\mathrm{Cu}(0.02 \mathrm{mg} / \mathrm{kg}$ dry weight $)<\mathrm{Cd}(0.05 \mathrm{mg} / \mathrm{kg}$ dry weight $)<\mathrm{Pb}(0.16 \mathrm{mg} / \mathrm{kg}$ dry weight $)<\mathrm{Zn}(0.45 \mathrm{mg} / \mathrm{kg}$ dry weight $)<\mathrm{Fe}(8,04 \mathrm{mg} / \mathrm{kg}$ dry weight) in Tushka khore.

The trend of accumulation was as follows: $\mathrm{Cu}$ and $\mathrm{Cd}$, EL-Madiq and Tushka < Amada and Dahmit, Pb, EL-Madiq < Amada $<$ Dahmit $<$ Tushka, Howevere Zn, Amada < Tushka < EL-Madiq < Dahmit, Fe, Amada < EL-Madiq < Dahmit < Tushka (Table 3).

The mean metals concentrations $(\mathrm{M}+\mathrm{SE})$ and bioaccumulation factor (BAF) of $O$. niloticus are shown in Table (3). The results showed that mean values of metal concentrations were ranked in the following orders $\mathrm{Fe}>\mathrm{Zn}>\mathrm{Cu}>\mathrm{Pb}>\mathrm{Cd}$ during winter and $\mathrm{Fe}>\mathrm{Zn}>\mathrm{Cd}>\mathrm{Pb}>$ $\mathrm{Cu}$ in the spring season. $\mathrm{Zn}$ and Fe have highest BAF of samples collected from Dahmit khore (4150 and 2457, respectively).

\section{Gills:}

Table (3) showed the concentrations of the analyzed metals in the gill fish from Nasser Lakes during the winter season. The metal concentrations in O. niloticus from Amada Khore were recorded. $\mathrm{Cu}(0.08 \mathrm{mg} / \mathrm{kg}$ dry weight $)<\mathrm{Cd}(0.3 \mathrm{mg} / \mathrm{kg}$ dry weight $)<\mathrm{Pb}(1.03$ $\mathrm{mg} / \mathrm{kg}$ dry weight $)<\mathrm{Zn}(3.36 \mathrm{mg} / \mathrm{kg}$ dry weight $)<\mathrm{Fe}(10.5 \mathrm{mg} / \mathrm{kg}$ dry weight $)$. From Khore EL-Madiq, metals detected, $\mathrm{Cu}(0.06 \mathrm{mg} / \mathrm{kg}$ dry weight $)<\mathrm{Cd}(0.4 \mathrm{mg} / \mathrm{kg}$ dry weight $)<\mathrm{Pb}$ $(1.1 \mathrm{mg} / \mathrm{kg}$ dry weight $)<\mathrm{Zn}(2.51 \mathrm{mg} / \mathrm{kg}$ dry weight $)<\mathrm{Fe}(7.62 \mathrm{mg} / \mathrm{kg}$ dry weight $)$. However, metal concentrations in the gills of fish from Dahmit khore were, $\mathrm{Cu}(0.13 \mathrm{mg} / \mathrm{kg}$ dry weight $)<\mathrm{Cd}(0.3 \mathrm{mg} / \mathrm{kg}$ dry weight $)<\mathrm{Pb}(0.06 \mathrm{mg} / \mathrm{kg}$ dry weight $)<\mathrm{Zn}(2.47 \mathrm{mg} / \mathrm{kg}$ dry weight $)<\mathrm{Fe}(10.14 \mathrm{mg} / \mathrm{kg}$ dry weight). While Tushka khore of the lake followed an abundance, $\mathrm{Cu}(0.07 \mathrm{mg} / \mathrm{kg}$ dry weight $)<\mathrm{Cd}(1.1 \mathrm{mg} / \mathrm{kg}$ dry weight $)<\mathrm{Pb}(1.3 \mathrm{mg} / \mathrm{kg}$ dry weight $)<\mathrm{Zn}(3.52 \mathrm{mg} / \mathrm{kg}$ dry weight $)<\mathrm{Fe}(12.54 \mathrm{mg} / \mathrm{kg}$ dry weight $)$ (Table 3$)$.

During spring season, metal concentrations in O. niloticus from four Khore of the Lake were detected as follow, $\mathrm{Cu}(0.2 \mathrm{mg} / \mathrm{kg}$ dry weight $)<\mathrm{Cd}(0.5 \mathrm{mg} / \mathrm{kg}$ dry weight $)<\mathrm{Pb}$ $(1.13 \mathrm{mg} / \mathrm{kg}$ dry weight $)<\mathrm{Zn}(4.16 \mathrm{mg} / \mathrm{kg}$ dry weight $)<\mathrm{Fe}(12.7 \mathrm{mg} / \mathrm{kg}$ dry weight $)$ in 
Hanan S. Gaber et al.

Amada khore, $\mathrm{Cu}(0.3 \mathrm{mg} / \mathrm{kg}$ dry weight $)<\mathrm{Cd}(0.7 \mathrm{mg} / \mathrm{kg}$ dry weight $)<\mathrm{Pb}(1.36 \mathrm{mg} / \mathrm{kg}$ dry weight $)<\mathrm{Zn}(3.23 \mathrm{mg} / \mathrm{kg}$ dry weight $)<\mathrm{Fe}(10.99 \mathrm{mg} / \mathrm{kg}$ dry weight $)$ in EL-Madiq khore. $\mathrm{Cu}$ $(0.18 \mathrm{mg} / \mathrm{kg}$ dry weight $)<\mathrm{Cd}(0.8 \mathrm{mg} / \mathrm{kg}$ dry weight $)<\mathrm{Pb}(0.8 \mathrm{mg} / \mathrm{kg}$ dry weight $)<\mathrm{Zn}$ $(2.92 \mathrm{mg} / \mathrm{kg}$ dry weight $)<\mathrm{Fe}(11.48 \mathrm{mg} / \mathrm{kg}$ dry weight $)$ in Dahmit khore, $\mathrm{Cu}(0.03 \mathrm{mg} / \mathrm{kg}$ dry weight $)<\mathrm{Cd}(1.47 \mathrm{mg} / \mathrm{kg}$ dry weight $)<\mathrm{Pb}(1.76 \mathrm{mg} / \mathrm{kg}$ dry weight $)<\mathrm{Zn}(3.37 \mathrm{mg} / \mathrm{kg}$ dry weight) $<\mathrm{Fe}(13.85 \mathrm{mg} / \mathrm{kg}$ dry weight) in Tushka khore (Table 3$)$.

The trend of accumulation was as follows, $\mathrm{Cu}$, Tushka $<$ Dahmit $<$ Amada $<$ ELMadiq, for, Cd Amada < El-Madiq < Dahmit < Tushka, for, Pb, Dahmit < Amda < EL-madik $<$ Tushka, for, Zn, Dahmit $<$ EL-Madiq < Tushka < Amada, for, Fe, EL-Madiq < Dahmit $<$ Amada $<$ Tushka (Table 3).

The results showed that metal concentrations were ranked in the following orders $\mathrm{Zn}>$ $\mathrm{Fe}>\mathrm{Pb}>\mathrm{Cd}>\mathrm{Cu}$ in Dahmit khore during the spring seasons and $\mathrm{Zn}$ listed highest BAF in Dahmit khore (7300). In the winter season, BAF of metals become lowest one.

Table (3): Mean metal concentrations (M+S.E) and bioaccumulation factor (BAF) in $O$. niloticus during the winter and the spring seasons (2016) in the studied khores.

\begin{tabular}{|c|c|c|c|c|c|c|c|c|c|}
\hline \multirow[b]{2}{*}{ Metals } & \multirow[t]{2}{*}{ Site } & \multirow[b]{2}{*}{ winter } & \multicolumn{2}{|l|}{ muscle } & \multirow[b]{2}{*}{ BAF } & \multicolumn{4}{|c|}{ gills } \\
\hline & & & BAF & spring & & winter & BAF & spring & BAF \\
\hline \multirow{4}{*}{$\mathrm{Fe}$} & Tushka & $4.48 \pm 0.7$ & 26.66 & $8.04 \pm 0.02$ & 33.36 & $12.04 \pm 0.4$ & 71.66 & $13.85 \pm 0.04$ & 57.46 \\
\hline & Amada & $4.49 \pm 0.18$ & 26.41 & $5.7 \pm 0.49$ & 25.9 & $10.50 \pm 0.28$ & 61.76 & $12.7 \pm 0.5$ & 57.72 \\
\hline & El-Madiq & $4.4 \pm 0.3$ & 30.13 & $6.67 \pm 0.06$ & 36.05 & $7.62 \pm 0.3$ & 54.42 & $10.99 \pm 0.1$ & 59.4 \\
\hline & Dahmit & $5.07 \pm 0.3$ & 33.8 & $6.88 \pm 0.24$ & 2457 & $10.14 \pm 0.6$ & 67.6 & $11.48 \pm 0.13$ & 4100 \\
\hline \multirow{4}{*}{$\mathrm{Zn}$} & Tushka & $0.67 \pm 0.11$ & 9.3 & $0.45 \pm 0.02$ & 8.03 & $3.52 \pm 0.03$ & 48.88 & $3.37 \pm 0.3$ & 60.17 \\
\hline & Amada & $0.22 \pm 0.04$ & 3.23 & $0.24 \pm 0.02$ & 3.42 & $3.36 \pm 0.26$ & 49.41 & $4.16 \pm 0.04$ & 46.14 \\
\hline & El-Madik & $0.65 \pm 0.02$ & 14.44 & $0.87 \pm 0.02$ & 16.41 & $2.51 \pm 0.04$ & 55.77 & $3.23 \pm 0.02$ & 832.21 \\
\hline & Dahmit & $1.41 \pm 0.2$ & 19.05 & $1.66 \pm 0.12$ & 4150 & $2.47 \pm 0.3$ & 33.37 & $2.92 \pm 0.01$ & 7300 \\
\hline \multirow[t]{4}{*}{$\mathrm{Cu}$} & Tushka & $0.03 \pm 0.02$ & 15 & $0.02 \pm 0.01$ & 5 & $0.07 \pm 0.02$ & 35 & $0.3 \pm 0.01$ & 75 \\
\hline & Amada & $0.05 \pm 0.02$ & 16.66 & $0.03 \pm 0.01$ & 15 & $0.08 \pm .01$ & 26.66 & $0.2 \pm 0.01$ & 100 \\
\hline & El-Madiq & $0.06 \pm 0.03$ & 30 & $0.02 \pm 0.01$ & 4.25 & $0.06 \pm 0.02$ & 30 & $0.3 \pm 0.01$ & 63.82 \\
\hline & Dahmit & $0.07 \pm 0.01$ & 28 & $0.06 \pm 0.03$ & 21.42 & $0.13 \pm 0.04$ & 52 & $0.18 \pm 0.06$ & 64.28 \\
\hline \multirow{4}{*}{$\mathrm{Pb}$} & Tushka & $0.14 \pm 0.02$ & 31.81 & $0.16 \pm 0.04$ & 30.7 & $1.3 \pm 0.3$ & 295.45 & $1.76 \pm 0.06$ & 338.46 \\
\hline & Amada & $0.04 \pm 0.01$ & 6,66 & $0.06 \pm 0.01$ & 7.5 & $1.03 \pm 0.03$ & 171 & $1.13 \pm 0.03$ & 141.25 \\
\hline & El-Madiq & $0.02 \pm 0.01$ & 2.02 & $0.05 \pm 0.01$ & 10 & $1.1 \pm 0.03$ & 157.14 & $1.36 \pm 0.16$ & 272 \\
\hline & Dahmit & $0.03 \pm 0.01$ & 5.17 & $0.07 \pm 0.01$ & 140 & $0.6 \pm 0.04$ & 103.44 & $0.8 \pm 0.03$ & 1600 \\
\hline \multirow{4}{*}{$\mathrm{Cd}$} & Tushka & $0.03 \pm 0.03$ & 9.37 & $0.05 \pm 0.01$ & 17.85 & $1.1 \pm 0.07$ & 343.75 & $1.47 \pm 0.03$ & 525 \\
\hline & Amada & $0.03 \pm 0.01$ & 15 & $0.08 \pm 0.01$ & 26.66 & $0.3 \pm 0.01$ & 150 & $0.5 \pm 0.02$ & 166.66 \\
\hline & El-Madiq & $0.02 \pm 0.01$ & 10 & $0.05 \pm 0.01$ & 16.66 & $0.4 \pm 0.09$ & 200 & $0.7 \pm 0.03$ & 233.33 \\
\hline & Dahmit & $0.05 \pm 0.02$ & 27.77 & $0.08 \pm 0.02$ & 114.28 & $0.3 \pm 0.01$ & 166.66 & $0.8 \pm 0.01$ & 1142.85 \\
\hline
\end{tabular}

\section{Histopathological observation:}

\section{1-Muscles:}

Histological results showed the normal structures of the muscles bundles (Fig. 2a). Several histopathological alterations were seen in the muscles of $O$. niloticus included degeneration in muscle bundles and vacuolar degeneration and atrophy of muscle bundles (Fig 2b). Edema and splitting of muscle fibers and focal areas of necrosis were also seen. These alterations were pronounced in the muscle of the studied fish from Tushka and Amada Khors during the winter season. In the spring season, the muscle of studied fish showed less alteration compared to those in the winter season, edema, splitting and atrophy of muscle bundles which more pronounced in EL-Madiq and Dahmit khores (Fig. 2c, d). 

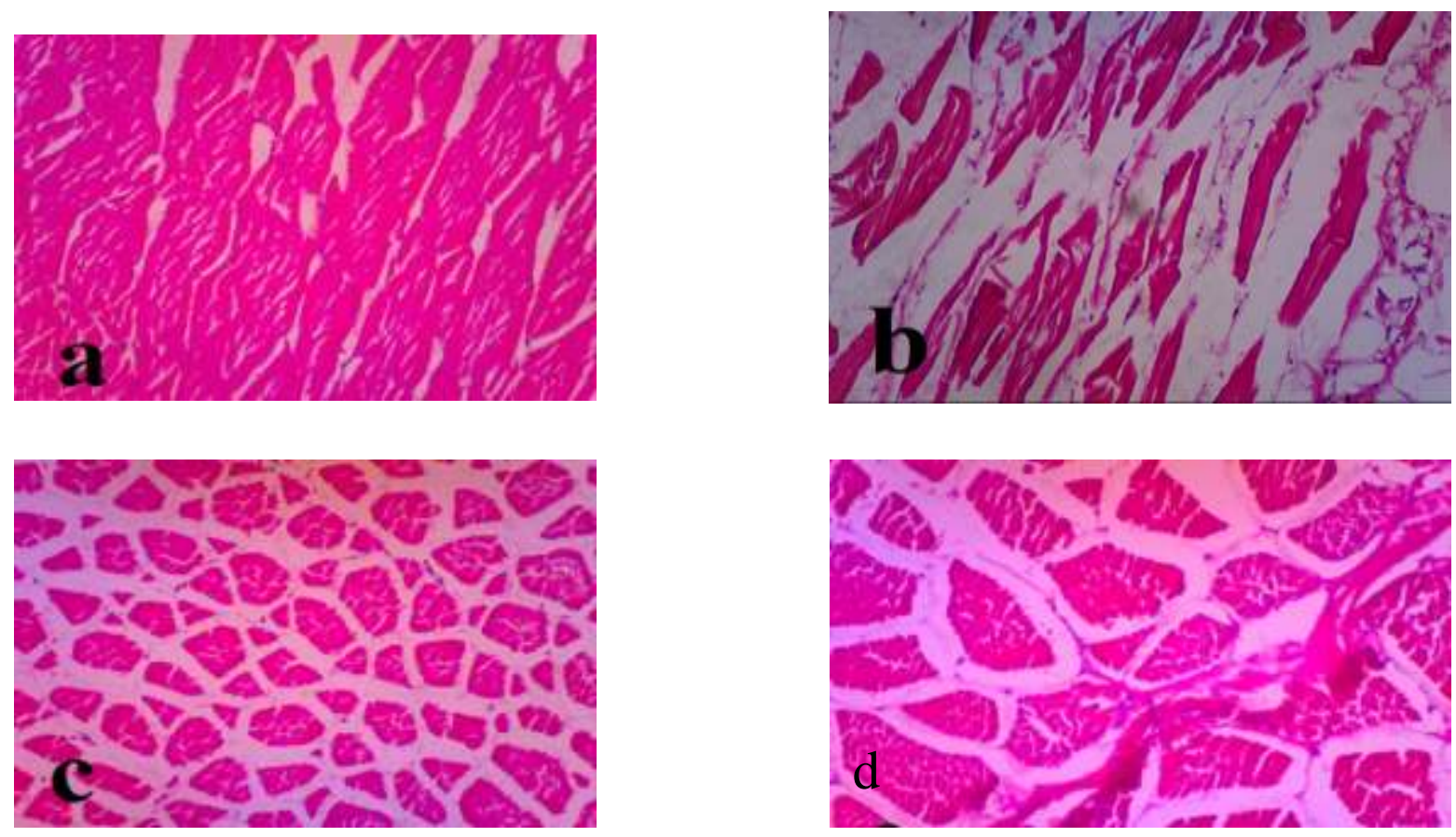

Fig.2. Sections of muscles of Oreochromis niloticus from Lake Nasser stained with, Hx\&E to show: a- normal structure of fish muscles (X100), b- atrophy of fish muscle fibers, muscle degeneration and vacuolar degeneration, c- severe edema and splitting muscle fibers (X 100) and (e) (X200).

\section{2-Gills:}

Sections from the control group of $O$. niloticus showed normal gills histology (Fig. 3a). The histopathological alterations in gills of the studied fish were more or less similar between khores in winter season. These include dilated, congestion of blood filament and necrotic change (Fig. 3b,c). In spring season in South part (Tushka, Amada, and EL-Madiq) these alterations are represented by congestion in the blood vessels of gill filaments, hyperplasia of epithelial cells which led to the fusion of lamellae and separation of the epithelium of the secondary lamellae from the lamellar supporting cells in some gill filaments, also intravascular hemolysis, degenerative and necrotic changes in gill lamellae (Fig. 4 b, c). The gills of fish samples collected from North Part (Dahmit khore) have severe degenerations and necrotic change (Fig $4 \mathrm{~d}$, e) in addition to loughing in the epithelium (Fig.4f). 
Hanan S. Gaber et al.
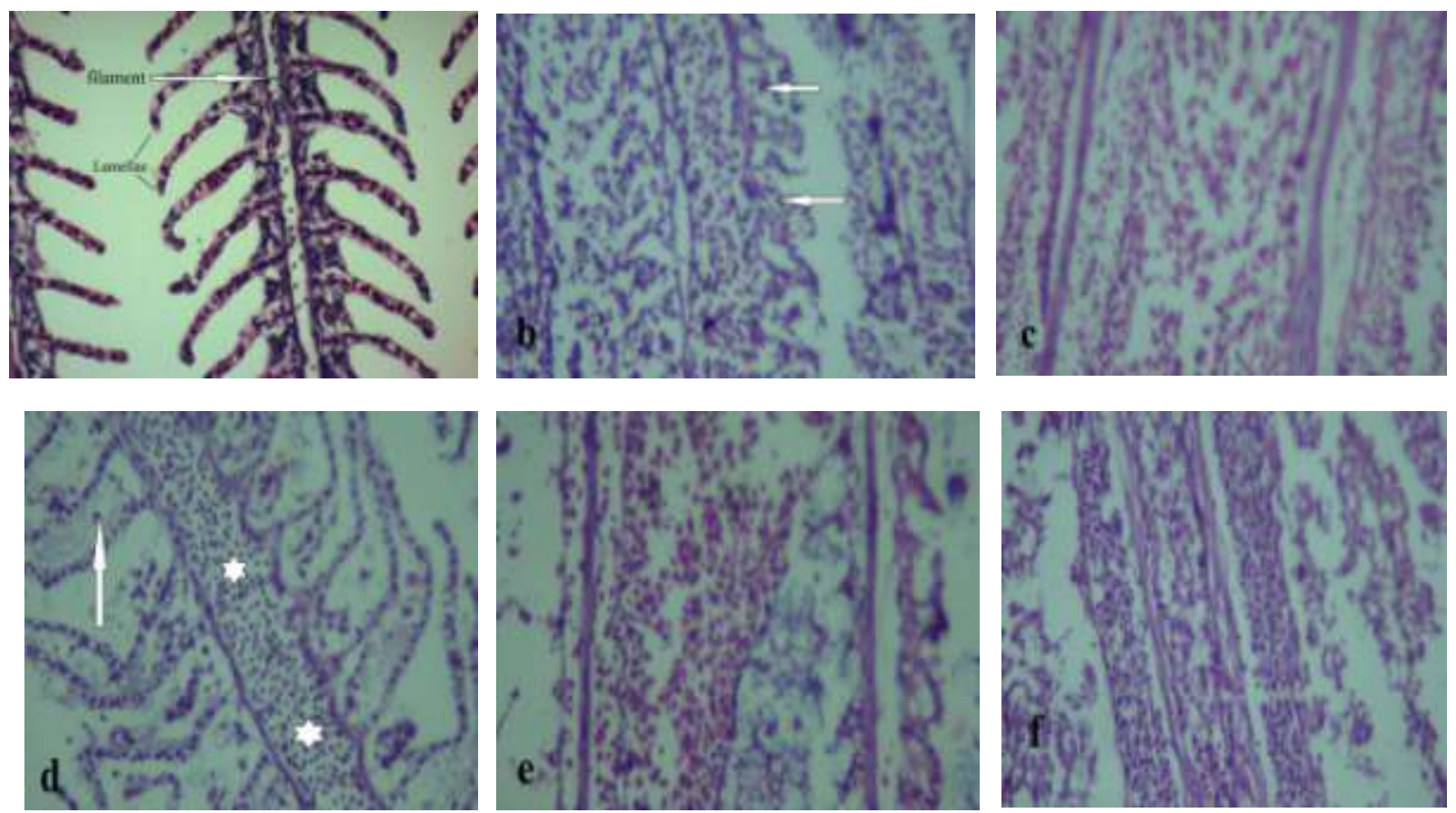

Fig. 3. Sections of gills of Oreochromis niloticus from Lake Nasser in winter stained with , Hx\&E to show: a- normal structure, filament(star), primary lamellae (arrows) (X400); b,c,d,e- dilated and congested blood vessel of gill filaments, severe necrotic change, congestion and Leukocytes infiltration; f-sloughing lamellae. X400).
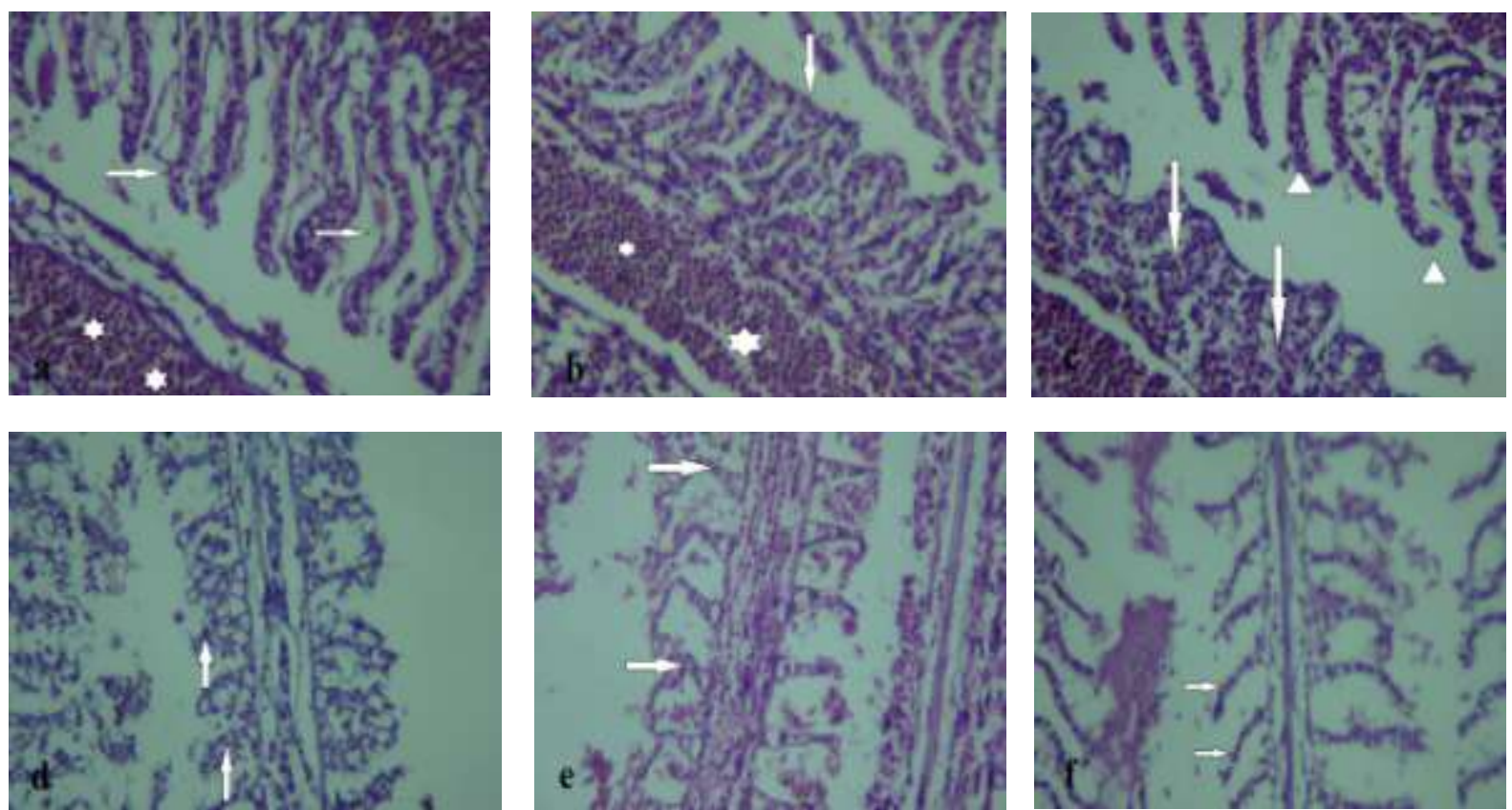

Fig. 4. Sections of gills of Oreochromis niloticus from Lake Nasser stained with, Hx \& E (X400) to show: a- gill alterations included, elongated lamella, epithelial lifting(arrows) leukocytes infiltrations(stars); b- severe hyperplasia led to lamellar fusion (arrow); cepithelial necrosis (arrows); d,e,f- severe epithelial necrosis(arrows). 


\section{Assessment of some heavy metals and histological alterations in gills and muscles of Oreochromis niloticus from Lake Nasser, Egypt}

\section{DISCUSSION}

The present results showed that the seasonal values of $\mathrm{pH}$ at studied Khores were (8.6 - 9.4) in winter and (8.0 - 9.1) in spring seasons at north part (Dahmit). While pH values were (8.3 - 9.0) and (8.2-8.6) in the winter and the spring of south part of Lake Nasser (at EL-Madiq-Amada-Tushka Khores), respectively. No wide variation in $\mathrm{pH}$ values for different studied Khores was found, while there were high $\mathrm{pH}$ values during spring especially in Khor Dahmit. This is may be related to the high nutrient salt during flood period consequently high primary production (Sayaah et al., 1988). Santhosh and Singh (2007) and Bhatnagar et al. (2013) stated that the acceptable $\mathrm{pH}$ range for fish culture was (6.7 to 9.5), while the ideal $\mathrm{pH}$ value lies between (7.5 and 8.5), above and below this value it will be stressful to the fish. The obtained data from the present study is accepted. WHO (1996) for drinking water reported that the ideal $\mathrm{pH}$ ranges between 7 to 8.0 , while the permissible range from 6.5 to 9.2 for different aquatic life. The increase in $\mathrm{pH}$ value led to an increase in organic contaminate in water (Brooks et al., 1997).

DO values were (6.1-9.1), (6.4-8.2) during winter and (2-8.3), (2.0-6.0) during the spring for Dahmit and (EL-Madiq-Amada-Tushka), respectively. DO mainly relate to the high rate of photosynthesis during these periods. Oxygen depletion in water leads to poor feeding of fish, starvation, reduced growth and more fish mortality, either directly or indirectly (Bhatnagar and Garg, 2000). In turn, the decrease in DO during the hot period considered normal results, as the amount of free oxygen decreases with the increase of the temperature (El- Haddad, 2005), during the period of study.

The range values BOD in winter was (0.6-2.1 and 0.8-3.1 mg-1), while it was (0.05.1 and 0.0-4.1mgl-1) in spring for Dahmit and (EL-Madiq-Amada-Tushka), respectively. The BOD value has a reversible relation with temperature, due to the depletion of free oxygen resulted from the increasing of water temperature. According to Ekubo and Abowei (2011), the aquatic system with BOD levels between $0.1-2.0 \mathrm{mgl}^{-1}$ considered clean; $3.0 \mathrm{mgl}^{-1}$ fairly clean; $5.0 \mathrm{mgl}^{-1}$ doubtful and $10 \mathrm{mgl}^{-1}$ definitely bad and polluted.

The total organic matter is functional of chemical oxygen demand (COD). The range values of COD in the studied Khors were (6.4-14.3 and 4.1-10.1 $\mathrm{mgl}^{-1}$ ) in the winter; (4.020.0and 2.0-12 $\mathrm{mgl}^{-1}$ ) in the spring for Dahmit and (EL-Madiq-Amada-Tushka). There is a reversible relationship between COD with temperature and positively correlated with DO and BOD. This means that COD is functional with both DO and BOD (Jordao et al., 2002 and Al Afify, 2006).

Ammonia is the by-product of protein metabolism excreted by fish and bacterial decomposition of organic matter (Table 1) such as wasted food, feces, dead planktons, sewage etc. The maximum limit of ammonia concentration for aquatic organisms is 0.1 $\mathrm{mgL}^{-1}$ (Meade, 1985: Santhosh and Singh, 2007). According to Swann (1997) the levels below $0.02 \mathrm{ppm}$ were considered safe. Ammonia recorded high values in winter and spring seasons and parts (north and south). Ammonia in the range $\left(>0.1 \mathrm{mgL}^{-1}\right)$ tends to cause gill damage, destroy mucous producing membranes, "sub-lethal" effects like reduced growth, and reduced disease resistance at concentrations that are lower than lethal concentrations. The maximum limit of ammonia concentration for aquatic organisms is $0.1 \mathrm{mgL}^{-1}$ (Meade, 1985: Santhosh and Singh, 2007).

The seasonal variation played a major role in metal ion speciation and the comparative concentrations of each metal and thereby availability for uptake by fish organs. In the present study winter represented the season where there was a decrease in temperature and $\mathrm{pH}$ of water which favors metals mobilization. These results are in harmony with those previously reported by Abdel-Satar and Shehata (2000) and Fayed (2004). Maanan (2008) suggested that the seasonal variations of metals bioaccumulation may be controlled by 


\section{Hanan S. Gaber et al.}

physicochemical parameters (temperature, dissolved oxygen, and $\mathrm{pH}$ ). In this study, there was a relationship between metals concentrations and physicochemical parameters. Peng et al. (2011) showed that the elevated temperature and the decrease in dissolved oxygen may increase the concentrations of dissolved metals and more metals will be taken up through the gills. Giarratano et al. (2011) showed that these variations could be attributed to seasonal changes in reproductive cycle and food availability leading to alterations in body weight and composition and to physiological processes.

The presence of trace metals in an aquatic ecosystem is an alarming problem worldwide. Fish have been introduced as excellent biological markers of metals in water since they occupy high trophic levels and are an important food source (Agah et al., 2009). In the present study, the concentrations of five trace metals ( $\mathrm{Fe}, \mathrm{Zn}, \mathrm{Cu}, \mathrm{Pb}$, and $\mathrm{Cd}$ ) detected in the studied khores water were less than their permissible limits given by the Egyptian Organization for Standardization (1993) and the Water Quality Standards USEPA. Although muscles of the studied fish accumulated least amount they are above the permissible limits in samples collected from Dahmit khore of the lake recommended by WHO (1996).

In this work muscles accumulated lesser copper than gills of O. niloticus. Similar results were observed in different fish species from El Max Bay Alexandria (Khaled, 2004). The investigated heavy metals in muscles of $O$. niloticus were ranked as $\mathrm{Fe}>\mathrm{Zn}>\mathrm{Cu}>\mathrm{Pb}<$ $\mathrm{Cd}$ in winter, while in spring the results showed $\mathrm{Fe}>\mathrm{Zn}>\mathrm{Cd}>\mathrm{Pb}>\mathrm{Cu}$. Their descending order in fish gills was $\mathrm{Fe}>\mathrm{Zn}>\mathrm{Pb}>\mathrm{Cd}>\mathrm{Cu}$ in winter and spring. The presence of trace metals inside the fish tissues is often affected by many external and internal factors. Metals concentration is correlated with ambient metals level in the surrounding environment, the available metal form in water, the structure of the target organ as well as the interaction between the metal and this organ (EL-Naggar et al., 2009). In the present study copper recorded the lowest concentration in water and in the gills, and muscles of the studied fish. This is mainly due to its tendency to form complex with organic legends and humic matter, which leads to decrease in the preparation of free ions in water where $90 \%$ of $\mathrm{Cu}$ in water was complexes by dissolved organic materials and suspended matter (Mantoura et al., 1978). Among all parts of fish under study, the gills accumulated the highest concentrations of $\mathrm{Zn}$, $\mathrm{Fe}, \mathrm{Cu}$ and $\mathrm{Pb}$ compared to those detected in muscles. This phenomenon is supported by the fact that gills are the first target organ for waterborne pollutants, since they participate in many important functions in fish, such as respiration, osmoregulation, and excretion, which makes them in close contact with the external environment and sensitive to changes in water quality (Au, 2004; Fernandes et al., 2008). In the present study, the lowest concentration of $\mathrm{Cu}$ was similar to results recorded by Yacoub (2007). This also agrees with the findings in other organs such as gills of $O$. niloticus (Abdel- Baki et al., 2011), Onchorynchus mykiss, $C$. carpio (De Boeck et al., 2004), O. niloticus (Mohamed, 2008). The concentration of $\mathrm{Cu}$ in water of the studied khores is still bellow the permissible level $(1.0 \mathrm{mg} / \mathrm{L})$ recommended by Egyptian Organization for Standardization, EOSQC (1993).

The highest accumulation of $\mathrm{Fe}$ was observed in organs such as gills in the fish Oreochromis niloticus and Lates niloticus (Mohamed, 2008), Liza aurata, Mugil cephalus, and Liza ramada (Uysal et al., 2008).

Although $\mathrm{Zn}$ is an essential element, at high concentrations, it can be toxic to fish, cause mortality, growth retardation and reproductive impairment (Sorenson, 1991). Zn is capable of interacting with other elements and producing antagonistic, additive or synergistic effects (Baumann and May 1984).

$\mathrm{Pb}$ is highly toxic to aquatic organisms, especially fish (Rompala et al., 1984). It is toxic even at low concentrations and has no known function in biochemical processes (Burden et al., 1998). Cd is a nonessential metal that is potentially toxic to most fish and wildlife, particularly freshwater organisms. 


\section{Assessment of some heavy metals and histological alterations in gills and muscles of Oreochromis niloticus from Lake Nasser, Egypt}

The present results indicated that the level of the investigated five heavy metals in muscles of $O$. niloticus was so far satisfactory and didn't constitute any threat to public health and human use. These results agree with those reported by Awadallah et al. (1985) and Rashed (2001).

Bioaccumulation Factor (BAF) gives an indication about the accumulation efficiency for any particular pollutant in any fish organ. BAF values recorded in the present study showed that for gills, BAF recorded the highest values at Dahmit khore during the spring season for $\mathrm{Zn}, \mathrm{Fe}, \mathrm{Pb}$ and $\mathrm{Cd}$ (7300, 4100, 1600, 1142, respectively). However, $\mathrm{Cu}$ listed lowest BAF value (64.28) at Dahmit and (100) at Amada during the spring season. During winter season BAF value for all the studied metals were the lowest. For muscles also BAF recorded the highest values at Dahmit khore during the spring season for $\mathrm{Zn}, \mathrm{Fe}, \mathrm{Pb}$ and $\mathrm{Cd}$ (4150, 2457, 140,114.2, respectively) and $\mathrm{Cu}$ recorded the lowest one. By comparing those values with the Waste Minimization Prioritization Tool (WMPT), it was shown that Cu was given score of 1 (low concern) for both gills and muscles of $O$. niloticus since their bioaccumulation factor (BAF) values were less than 250 , while $\mathrm{Fe}, \mathrm{Zn}, \mathrm{Pb}$ and $\mathrm{Cd}$ given high score where its BAF values was higher than 1000 . These results showed that O. niloticus fish collected from Dahmit khore in Lake Nasser can undergo bioaccumulation of $\mathrm{Fe}, \mathrm{Zn}, \mathrm{Pb}$, and $\mathrm{Cd}$ metal in their gills, while muscles accumulate high concentration of $\mathrm{Fe}$ and $\mathrm{Zn}$ during the spring season (Abdel-Baki et al., 2011).

The present results indicated the presence of several histopathological alterations in muscles of $O$. niloticus including degeneration in muscle bundles and large fat vacuoles and atrophy of muscle bundles. Edema and splitting of muscle fibers were also seen. Alterations were more severe in the muscle of studied fish collected from Khore Tushka and Amada in winter season. In the spring season, the muscle of the studied fish showed edema, splitting and atrophy of muscle bundles and focal areas of necrosis which more pronounced in khore Dahmit and El- Madiq. The present results was in agreement with those observed by many authors' investigators who have studied the effects of different pollutants on muscles of Tilapia nilotica (Sakr and Gabr, 1991), Nile catfish Clarias lazera (Abo-Nour and Amer, 1995) and carp Labeo rohita (Das, and Mukherjee, 2000). Also, Mohamed (2009) reported the same histological alterations in the muscles of T. Zillii and S. vulgaris from Lake Qarun during summer and winter, also, vacuolar degeneration in muscle bundles and atrophy that are observed in the muscle bundles might be due to the various concentrations of the mixture of heavy metals.

In this study, vacuolation of gill epithelial cells in fish samples from Tushka and Dahmit khores was we noted in the spring season. This may indicate a failure to regulate water content. A further hypothesis is that subcuticular vacuoles provide a long pathway for water movement, decreasing its rate of entry into the cell. Vacuolation of epithelial cells will potentially affect the physiological processes in the gill by increasing the diffusion distance for respiratory gases and ions (Lawson et al., 1995). This lesion was frequently observed in the gill cells of $C$. maenas following copper exposure (Lawson et al., 1995). The histology of gills of $O$. niloticus demonstrated that the hemocyte infiltration, abnormal gill tips, malformation at the tip of the gill, necrotic gill lamellae and vacuolization of epithelial cells are interesting histopathological biomarkers for heavy metal-induced stress. The necrotic gill lamellae is another aspect of alterations. The present results are in accordance with those of Saravana et al. (2000) in prawn Macrobrachium malcolmsonii exposed to the organochlorine pesticide. The necrotic gill lamellae were also reported in gills of the mussel Perna viridis exposed in the field to the mixture of metals (Arockia Vasanthi et al., 2012; Gaber et al., 2014). The gill of $O$. niloticus in Dahmit khore have lesions included severe necrotic change and degeneration. Similar findings have been reported for other fish species that are exposed 


\section{Hanan S. Gaber et al.}

to different pollutants (Olurin et al., 2006). Camargo and Martinez (2007) observed hyperplasia of the epithelial cells, the fusion of secondary lamellae, lifting of the lamellar epithelium and blood congestion in the gills of P. lineatus being caged in Brazilian Cambé stream being polluted by the industrial, domestic and agricultural wastes. Lamellar vasodilation was formed in the studied fish exposed to $\mathrm{Zn}$ and $\mathrm{Cd}$. it was referred that this lesion can induce changes in pillar cell normal structure, with consequent loss of their support fraction (Garcia-Santos et al., 2006).

The results of this study supply valuable information about some heavy metal recorded in the water from four khores (EL-Madiq, Amada, Tushka, and Dahmit) from Lake Nasser, and level of this metals accumulated in some organs of Oreochromis niloticus in compared with their histological features. The higher levels of trace metals in fish may result in toxic effects on humans.

\section{REFERENCES}

Abdel-Baki, A.S.; Dkhil, M.A. and Al-Quraishy, S. (2011). Bioaccumulation of some heavy metals in tilapia fish relevant to their concentration in water and sediment of Wadi Hanifah, Saudi Arabia. Afr. J. Biotechnol., 10 (13): 2541- 2547.

Abdel-Satar, A.M. and Shehata, M.B. (2000). Heavy metals accumulation and macronutrient contents in the flesh of two edible fish inhibiting the River Nile, Egypt. J. Egypt. Acad. Soc. Environ. Develop. 1 (1): 99 - 117.

Abo Nour, A. and A. Amer (1995). Impairment of muscle performance in the Nile catfish Clarias lazera in response to hostathion insecticide contamination and/or gamma irradiation. J. Egypt. Ger. Soc. Zool.,18:153-175.

Agah, H.; Leermakers, M.; Fatemi, S.M.R. and Baeyens, W. (2009). Accumulation of trace metals in the muscles and liver tissues of five fish species from the Persian Gulf. Environ. Monit. Assess., 157: 499-514.

AL-Afify A.D. (2006). Biochemical studies on River Nile Pollution. M.Sc. Thesis, Fac. Agricul. Cairo, Univ. Cairo Egypt.

APHA, (1998). Standard methods for analysis of water and waste water. $20^{\text {th }}$ Ed. American Public HealthAssociation, Inc., Washington DC.

Arockia, V.L.; Revathi, P.; Arulvasu, C. and Munuswamy, N. (2012). Biomarkers of metal toxicity and histology of Perna viridis from Ennore estuary, Chennai, South East Coast of India. J. Ecotoxicol. Environ. Saf., 84: 92-98.

Au, D.W.T. (2004). The application of histocytopathological biomarkers in marine pollution monitoring. A review, Mar. Pollut. Bull., 48: 817- 834.

Authman, M.M.N. and H.H.H. Abbas (2007). Accumulation and distribution of copper and zinc in both water and some vital tissues of two fish species (Tilapia zillii and Mugil cephalus) of Lake Qarun, Fayoum Province, Egypt. Pak. J. Biol. Sci., 10: 2106-2122.

Awadallah, R.M.; Mohamed, A. E. and Gaber, S.A. (1985). Determination of trace elements in fish by instrumental neutron activation analysis. J. Radioanal. Nucl. Chem. Lett., 95(3): 450-454.

Baumann, P.C. and May, T.W. (1984). Nickel residues in fish from inland waters of the United States. Workshop Proceedings, the Effects of trace elements on Aquatic Ecosystems. Electr. Pow. Res. Instit. Palo Alto, CA, 7: 1-16.

Bhatnagar, A. and Garg, S.K., (2000). Causative factors of fish mortality in still water fish ponds under sub-tropical conditions, Aquaculture, 1(2): 91-96.

Bhatnagar, A. and Devi, P. (2013). Water quality guidelines for the management of pond fish culture. Inter. J. Environ. Sci., 3(6): 1980-2009. 


\section{Assessment of some heavy metals and histological alterations in gills and muscles of Oreochromis niloticus from Lake Nasser, Egypt}

Brooks, K.N.; Ffolliott, P.F; Gregersen, H. M. and DeBano, L.F. (1997). Hydrology and the Management of Watersheds. $2^{\text {nd }}$ edition. Iowa State University Press Ames, Iowa, 209 $-234$.

Burden, V.M.; Sandheinrich, M.B. and Caldwell, C.A. (1998). Effects of lead on the growth and aaminolvulinic acid dehydratase activity of juvenile rainbow trout, Oncorhynchus mykiss. Environ. Poll., 101: 285- 289.

Burridge, L.E.; Doe, K.; Haya, K.; Jackman, P.M.; Lindsoy, G. and Zitko, V. (1999). Chemical analyses and toxicity tests on sediments under salmon net pens in the Bay of Fundy. Can. Tech. Rep. Fish. Aquat. Sci., 2291:39.

Camargo, M.M. and Martinez, C.B. ( 2007): Histopathology of gills, kidney, and liver of a Neotropical fish caged in an urban stream. Neotrop. Ichthyol., 5: 327-336.

Das, B.K. and Mukherjee, S.C. (2000). A histological study of carp Labeo rohita exposed to hexachlorocyclohexane. Vet. Archiv., 70(4): 169-180.

De Boeck, G., Meeus, W., De Coen, W., Blust, R. (2004): Tissue-specific Cu bioaccumulation patterns and differences in sensitivity to waterborne $\mathrm{Cu}$ in three freshwater fish: rainbow trout (Oncorhynchus mykiss), common carp (Cyprinus carpio), and gibel carp (Carassius auratus gibelio). Aquat.Toxicol. 70, 179-188.

Ekubo, A.A. and Abowei, J.F.N. (2011). Review of some water quality management principles in culture fisheries. Res. J. Appl. Sci., Engineer. and Technol., 3(2):13421357.

El-Haddad, E.S. (2005). Physicochemical studies for domestic water for Ismailia canal from El-Mazalat to Anshas. M.Sc Thesis Faculty of Science, Al Azhar University, Cairo Egypt.

El-Naggar, A.M.; Mahmoud, S.A. and Tayel, S.I. (2009). Bioaccumulation of some heavy metals and histopathological alterations in liver of Oreochromis niloticus in relation to water quality at different localities along the River Nile, Egypt. World J. Fish and Mar. Sci., 1 (2): 105-114.

EOSQC (Egyptian Organization for Standardization and Quality Control) (1993): Maximum residue limits for heavy metals in food. Ministry of Industry. No. 2360/1993.

Fayed, D.B. (2004). Aspects of Manzalah Lake pollution on Mugil species. M.Sc. Thesis, Faculty of Science. Ain Shams University, Egypt.

Fernandes, C.; Fontainhas-Fernandes, A.; Cabral, D. and Salgado, M. A. (2008). Heavy metals in water, sediment and tissues of Liza saliens from Esmoriz paramos lagoon, Portugal. Environ. Monit. Assess., 136: 267 - 275.

Gaber, H.S, Ibrahim, S. A, EL- Kasheif, M. A and El-Ghamadi, F. A.(2014): Comparison of Tissue Lesions in Two Species of Marine Fish (Solea solea and Mugil cephalus) Inhabiting Bardawil Lagoon, Research Journal of Pharmaceutical, Biological and Chemical Sciences. 5(5) Page No. 62-74.

Ghazaly, K S. (1988). The bioaccumulation of potential heavy metals in the tissues of the Egyptian edible marine animals. Part I. Crustaceans. Bull. Nat. Inst. Oceanogr. Fish., ARE, 14: 71-77.

Giarratano, E.; Gil, M.N. and Malanga, G. (2011). Seasonal and pollution-induced variations in biomarkers of transplanted mussels within the Beagle Channel. Mar. Pollut. Bull., 62:1337-1344.

Jordao, C.P.; Pereira, M.G.; Bellato, C.R.; Pereira, J.L .and Matos, A.T. (2002). Assessment of water systems for contaminants from domestic and industrial sewages. Environ. Monit. Assess., 79: 75-100. 


\section{Hanan S. Gaber et al.}

Khaled, A. (2004). Heavy metals concentrations in certain tissues of five commercially important fishes from El-Max bay, Alexandria, Egypt. Egypt. J. Aquat. Biol. Fish., 8 (1): 51-64

Lawson, N.D.; Stillman, E.A.; Whitt, M.A. and Rose, J.K. (1995). Recombinant vesicular stomatitis viruses from DNA. Proc. Nat. Acad. Sci. USA, 92: 4477-4481.

López-Barea, J. (1995). Biomarkers in Ecotoxicology: an Overview - Archives of Toxicology 17: 57-79.

Maanan, M. (2008): Heavy metal concentrations in marine mollusks from the Moroccan coastal region. Environ Pollut 153:176-183.

Mantoura, R.F.C.; Dickson, A. and Riley, J.P. (1978). The complexation of metals with humic materials in natural waters. Estuar. Coast. Mar. Sci., 6: 387-408.

Meade, J.W. (1985). Allowable ammonia for fish culture, Progressive Fish culture, 47, pp 135-145.

Mohamed, FA. (2008). Bioaccumulation of selected metals and histopathological alterations in tissues of Oreochromis niloticus and Lates niloticus from Lake Nasser, Egypt. Global Veterinaria, 4(2): 205-218.

Mohamed, F.A. (2009). Histopathological studies on Tilapia zilliiand Solea vulgaris from Lake Qarun, Egypt. World J. Fish. and Mar. Sci.. 1(1): 29-39.

Olurin, K.; Olojo, E.; Mbaka, G. and Akindele, A. (2006). Histopathological responses of the gill and liver tissue of Clarias gariepinus fingerlings to the herbicide, glyphosate. Afr. J. Biotechnol., 5: 2480-2487.

Peng, S.H.; Hung, J.H. and Hwang, J.S. (2011). Bioaccumulation of trace metals in the submarine hydrothermal vent crab Xenograpsus testudinatus off Kueishan Island, Taiwan. Mar. Pollut. Bull., 63(5-12):396-401.

Poleksić, V.; Lenhardt, M.; Jarić, I.; Djordjević, D.; Gačić, Z.; Cvijanović, G. and Rašković, B. (2010). Liver, gills, and skin histopathology and heavy metal content of the Danube sterlet (Acipenser ruthenus Linnaeus, 1758). Environ. Toxicol. and Chem., 29:515-521

Rashed, M.N. (2001). Monitoring of environmental heavy metals in fish from Nasser Lake. Environ. Inter., 27:27-33

Rompala J.M.; Rutosky, F.W. and Putnam, D.J. (1984). Concentrations of environmental contaminants from selected waters in Pennsylvania. U.S. Fish Wildl. Serv. Rep., State College, Pennsylvania., pp 102

Sakr, S. and S. Gabr. (1991). Ultrastructural changes induced by diazinon and neopybuthrin in skeletal muscles of Tilapia nilotica. Proceed. Zool. Soc.A.R.E., 21: 1-14.

Santhosh, B. and Singh, N.P. (2007). Guidelines for water quality management for fish culture in Tripura, ICAR Research Complex for NEH Region, Tripura Center, Publication no.29.

Saravana, B.P. and Geraldine, P. (2000). Histopathology of the hepatopancreas and gills of the prawn Macrobrachium malcolmsonii exposed to endosulfan. Aquat. Toxicol., 50: 331-339.

Sayyaah, S.M.; Elewa, A.A.; Latif, A.F.A. and Toufeek, M.E.F. (1988). The major anions and cations in Lake Nasser - River Nile water in Aswan Egypt Bull. Inst. Ocean \& Fish., 14(3): 213-226.

Seymore, T. (1994). Bioaccumulation of metals in Barbus marequensis from the Olifants River, Kruger National Park, and lethal levels of Mn to juvenile Oreochromis mossambicus . M.Sc. thesis, Rand Afrikaans University, South Africa.

Sorenson, E.M. (1991). Metal Poisoning in Fish. CRC Press, Inc. Boca Raton, Florida, 1991, pp 119-174 


\section{Assessment of some heavy metals and histological alterations in gills and muscles of Oreochromis niloticus from Lake Nasser, Egypt}

Swann, L.D. (1997). A Fish Farmer's Guide to Understanding Water Quality, Aquaculture Extension Illinois, Purdue University, Indiana Sea Grant Program Fact Sheet AS-503.

Uysal, K.; Yilmaz, E. and Koca, E. (2008). The determination of heavy metal accumulation ratios in muscles, skin, and gills of some migratory fish species by inductively coupled plasma-optical emission spectrometry (ICP- OES) in Beymelek Lagoon (Antalya/ Turkey), Microchem. J., 90:67-70.

WHO World Health Organization (1996). Guidelines for drinking water quality, vol. 2, $2^{\text {nd }}$ ed ) Geneva: World Health Organization.

Yacoub, A.M. (2007). Study on some heavy metals accumulated in some organs of three River Nile fishes from Cairo and Kalubia governorates. Afr. J. Biol. Sci., 3(3):9- 21

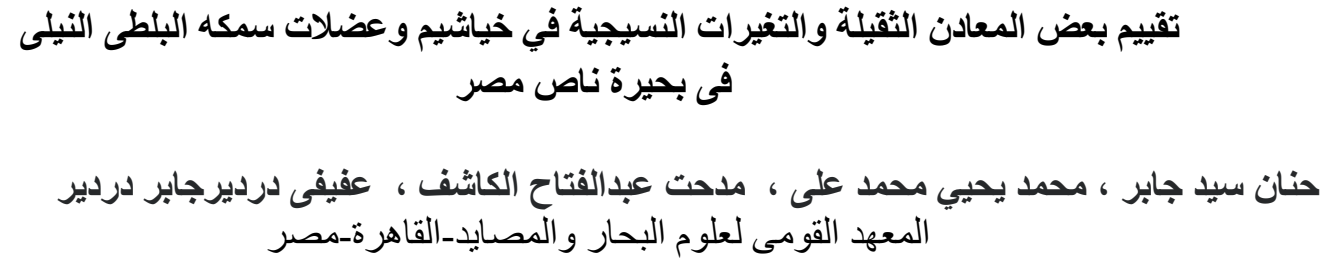

